\title{
PENERAPAN DISCOVERY LEARNING UNTUK MENANAMKAN KARAKTER KEWIRAUSAHAAN MAHASISWA PADA MATA KULIAH MANAJEMEN RITEL
}

\author{
Maisaroh \\ Prodi D3 Manajemen Perusahaan Fakultas Ekonomi Universitas Islam Indonesia \\ Email : maisaroh@uii.ac.id
}

\begin{abstract}
Abstrak
Penelitian ini merupakan pengembangan metode pembelajaran melalui tindakan kelas menggunakan metode pembelajaran discovery learning, pada mata kuliah Manajemen Ritel. Sebelum dilakukan proses belajar mengajar, dosen melakukan pengembangan metode pembelajaran, yang dimulai dengan merancang pengembangan desain instruksional yang terdiri dari tujuan pembelajaran, penilaian, dan pelaksanaan pembelajaran. Proses pembelajaran dilaksanakan selama 16 kali pertemuan, yang terbagi dalam 4 Capaian Pembelajaran Mata Kuliah (CPMK). Metode discovery learning dalam penelitian ini dijabarkan dalam penggunaan tehnik pembelajaran yang mengintegrasikan tiga tehnik sekaligus, yaitu magang industri, bedah kasus, dan diskusi kelompok. Berdasarkan hasil pembelajaran dapat disimpulkan bahwa seluruh CPMK terpenuhi yaitu $\geq 79 \%$. Tingkat keaktifan dan kehadiran mahasiswa juga mencapai $\geq 79,5 \%$. Hasil menunjukkan bahwa metode discovery learning memberikan dampak positif dalam membangun karakter kewiausahaan mahasiswa, dilihat dari kriteria penilaian kemampuan kognitif (berupa penguasaan materi) dan kemampuan afektif (kreatifitas, keaktifan, kehadiran, keberanian mengemukakan pendapat). Disisi lain, produktifitas dosen juga tergambar dalam capaian keluaran berupa ketersedian RPS, RPP magang, handout, serta SOP magang. Selain itu ada peningkatan kinerja dosen berdasarkan penilaian mahasiswa, dari 3,2 di semester sebelumnya, menjadi 3,7 di semester bersangkutan. Ini mencerminkan bahwa metode discovery learning memberikan dampak positif dalam proses pembelajaran, baik bagi mahasiswa maupun dosen.
\end{abstract}

Kata Kunci: Manajemen ritel, kewirausahaan, karakter kewirausahaan, pembelajaran discoveri

\section{Abstract}

This research tried to develop the learning method through class action using discovery learning methods, on Retail Management classes. Before learning process is carried out, the lecturer developed learning methods, began with designing instructional learning, consisted of the objectives of learning, assessment, and 
implementation of learning. The learning process was held during 16 meetings, divided into 4 learning outcomes. The discovery learning in this research then elaborated used three learning techniques, those are an industrial internship, case study, and group discussions. Based on the results, all learning outcomes are achieved, with value for every learning outcome $\geq 79 \%$. The level of activeness and the presence of students are $\geq 79.5 \%$. It shows that the discovery learning method gives a positive impact in building the entrepreneurship character, both from aspect cognitive abilities (in the form of mastery of material) and aspect affective abilities (creativity, activeness, presence, the courage to express opinions). Besides that the productivity and performance of lecturers also achieved. Those can be seen from the availability of learning tools, and performance measurement from 3.2 in the previous semester to 3.7 in the relevant semester. It means the discovery learning method has a positive impact on the learning process, both for students and lecturer.

Keywords: Retail Management, Entreprenuerhip, Entrepreneur character, Discovery Learning

\section{PENDAHULUAN}

Kurikulum
Berbasis

Kompetensi (KBK) yang mengacu pada KKNI (Kerangka Kualifikasi Nasional Indonesia), membangun pemahaman bahwa kompetensi seorang lulusan tidak lagi hanya dipandang semata dari ijasah, tetapi dengan melihat kerangka kualifikasi yang disepakati secara nasional sebagai dasar pengakuan terhadap hasil pendidikan seseorang secara luas sesuai dengan kebutuhan pasar. Pelaksanaan KBK sendiri, mensyaratkan beberapa kondisi, salah satunya adalah proses pembelajaran yang ber pusat pada siswa (student learning centre). Terkait dengan hal tersebut, peran pengajar di kelas sudah bukan lagi sebagai sumber ilmu saja, dia memiliki peran yang lebih luas untuk menjadi motivator, dinamisator sekaligus menjadi katalisator proses belajar mengajar di kelas. Dalam pembelajaran yang ber pusat pada siswa, guru akan mendorong siswa untuk aktif dalam membangun konsep keilmuan secara mandiri baik secara individu atau berkelompok. Tentu saja konsekwensinya, peran guru di kelas menjadi berkurang, tehnik ceramah oleh guru juga akan berkurang. Dampak positif nya bagi siswa menjadi lebih mandiri dalam belajar, bisa mengembangkan pola pikir nya, serta membangun daya analitis.

Mata kuliah Manajemen Ritel adalah salah satu mata kuliah kompetensi yang ditawarkan oleh Prodi Manajemen D3 UII. salah satu mata kuliah kompetensi, maka proses pembelajaran yang dilakukan di kelas tidak bisa hanya dilakukan dengan metode yang monoton, tetapi harus dengan metode yang bervariasi untuk memberikan ketrampilan pada mahasiswa terkait dengan manajemen ritel. Selain itu juga dalam rangka merespon perkembangan praktek bisnis ritel di Indonesia yang semakin pesat. Bisnis ritel saat ini berkembang tidak hanya mengandalkan cara manajemen ritel tradisional, tetapi sesuai perkembangan jaman, praktek 
bisnis ritel sudah banyak melibatkan kecanggihan tehnologi dan informasi.

Dalam rangka memenuhi tujuan pembelajaran, maka materi yang diajarkan tidak sekedar menggunakan penjelasan teori, tetapi juga terkait dengan ketrampilan mengenai pengelolaan bisnis ritel modern mulai dari konsep dasar hingga praktek singkat. Beberapa materi yang diajarkan dalam mata kuliah ini antara lain teori dasar dan perkembangan bisnis ritel, manajemen bisnis toko ritel, serta trend bisnis ritel saat ini. Dengan demikian, setelah lulus, mahasiswa diharapkan menjadi sumber daya manusia profesional untuk mengelola bisnis ritel baik sebagai pengusaha maupun pekerja.

Berdasarkan pengalaman, proses pembelajaran mata kuliah Manajemen ritel yang dilakukan dosen di Prodi D3 Manajemen UII sudah berusaha menggunakan metode student centre learning dengan menggabungkan antara ceramah dan diskusi kelompok. Akan tetapi pelaksanaannya masih tetap di dominasi oleh ceramah dosen dengan porsi ceramah dibanding diskusi adalah 60:40. Selain itu, proses pembelajaran belum memasukkan sesi praktek pengelolaan bisnis ritel. Hasilnya, secara koknitif, sebagian besar mahasiswa bisa memahami konsep yang sudah diajarkan. Hal ini terbukti dengan pencapaian nilai yang memuaskan dari kelas yang di ampu. Akan tetapi pencapaian pembelajaran dari aspek sikap dan ketrampilan masih kurang. Penilaian ini digali oleh dosen saat mahasiswa melakukan presentasi business plan, sebagian besar dari mahasiswa masih belum menunjukkan motivasi yang tinggi untuk berwirausaha. Padahal kompetensi yang ingin dibangun dari mata kuliah ini, siswa diharapkan bukan sekedar faham dengan teori saja, akan tetapi juga terbangun karakter kewirausahaannya, serta memiliki ketrampilan dalam pengelolaan bisnis ritel.

Sudah banyak peneliti yang mencoba meneliti hubungan antara hubungan pendidikan kewirausahaan dan karakter kewirausahaan. Lorz (2008) dalam penelitiannya yang berjudul The Impact of Entrepreneurship Education on Entrepreneurial Intention, menyebutkan bahwa pendidikan kewirausahaan berpengaruh positif terhadap pembentukan karakter kewirausahaan sekaligus intensi kewirausahaan. Hermansyah, Natuda, dan Sumarno (2017), dalam penelitiaannya dengan judul Kontribusi Pelaksanaan Pembelajaran Kewirausahaan dan Interaksi Sosial Terhadap Karakter Kewirausahaan Peserta Didik MAN 1 Pekanbaru, menghasilkan kesimpulan bahwa pelaksanaan pembelajaran kewirausahaan dan interaksi sosial memiliki pengaruh positif terhadap pembentukan karakteristik kewirausahaan siswa. Maisaroh dan Dharmawan (2017), dalam penelitiaannya tentang pengaruh pendidikan kewirausahan dan self efficacy terhadap intensi kewirausahaan, juga menyebutkan bahwa baik pendidikan kewirausahaan dan self efficacy memiliki pengaruh positif terhadap intensi kewirausahaan. Dari ketiga penelitian diatas, dapat dilihat bahwa pendidikan kewirausahaan memiliki peranan positif dalam pembentukna 
karakter dan intensi kewirausahaan. Akan tetapi kajian langsung terkait bagaimana proses dan metode pembelajaran yang dapat mempengaruhi pembentukan karakter oleh para peneliti di atas masih belum dilakukan. Oleh karena itu dalam penelitian kali ini, akan dilakukan kajian tentang metode pembelajaran discovery learning dan kontribusinya dalam pembentukan karakter kewirausahaan mahasiswa.

Berdasarkan kondisi di atas, maka peneliti tertarik untuk melakukan penelitian terkait inovasi pembelajaran, dengan menggunakan pendekatan student learning centre. Model pembelajaran yang digunakan adalah discovery learning, dengan mengintegrasikan tehnik/metode pembelajaran magang industri bedah kasus - praktek perencanaan bisnis diterapkan secara bersamasama dalam proses pembelajaran mata kuliah manajemen ritel. Tentu saja ceramah tetap digunakan tetapi dengan porsi yang berkurang. Secara lebih rinci gambaran pelaksanaan pembelajaran akan melibatkan seluruh mahasiswa untuk mengikuti proses magang, yang tujuannya untuk memberikan pengalaman mahasiswa untuk mengelola bisnis ritel. Kemudian, setelah proses magang selesai, di kelas mahasiswa didampingi dosen akan membedah kasus-kasus yang dialami selama magang. Dan diakhir kuliah mereka akan membuat proposal perencanaan pengembangan bisnis yang akan ditawarkan kepada lembaga tempat mereka magang.

Tujuan dari penelitian ini adalah untuk mendeskripsikan proses pembelajaran mata kuliah manajemen ritel dengan menggunakan model discovery learning. Selain itu juga menumbuhkan karakter kewirausahaan mahasiswa yang mengambil mata kuliah manajemen ritel. Sedangkan rumusan masalah penelitian adalah sebagai berikut :

1. Bagaimana model discovery learning diterapkan dalam proses pembelajaran mata kuliah manajemen ritel?

2. Apakah model discovery learning dapat menumbuhkan karakter kewirausahaan mahasiswa yang mengambil mata kuliah $\mathrm{m}$

3. anajemen ritel?

\section{METODE}

\section{Responden Penelitian}

Responden dalam penelitian ini adalah mahasiswa D3 manajemen yang sedang mengambil mata kuliah Manajemen Ritel semester ganjil 2017/2018. Jumlah seluruh siswa ada 78 mahasiswa.

\section{Tehnik Pengumpulan Data}

Karakter kewirausahaan mahasiswa dalam penelitian ini dinilai menggunakan kriteria penilaian kemampuan kognitif berupa penguasaan materi dan kemampuan afektif seperti kreatifitas, keaktifan, kehadiran, keberanian mengemukakan pendapat. Cara penilaian dengan menggunakan rubrik penilaian dengan menggunakan media berupa pemberian tugas/tes yang diberikan di setiap level pencapaian pembelajaran, dan berdasarkan pengamatan proses pembelajaran keseharian.

\section{Desain dan Rancangan Penelitian}


Penelitian ini merupakan pengembangan metode pembelajaran melalui tindakan kelas. Mata kuliah yang diampu adalah Manajemen Ritel, dengan menggunakan metode pembelajaran discovery learning. Sebelum dilakukan proses belajar mengajar, sebelumnya dosen pengembangan metode pembelajaran, yang dimulai dengan merancang pengembangan desain instruksional yang terdiri dari tujuan pembelajaran, penilaian, dan pelaksanaan pembelajaran. Langkah kedua adalah perencanaan assesment yang akan digunakan untuk mengukur ketercapaian pembelajaran. Assesment yang digunakan berupa penugasan kelompok, dimana mahasiswa diberikan tugas secara berkelompok untuk mengukur ketercapaian CPMK dan karakter kewirausahaan yang sudah terbangun selama proses belajar mengajar. Kriteria penilaian menggunakan penilaian berdasarkan rubrik yang disusun, dengan kriteria masingmasing rubrik berbeda berdasarkan jenis penugasan. Ada tiga jenis penugasan yang diberikan kepada mahasiswa, yaitu tugas analisis peta konsep, studi kasus, dan penyusunan proposal business plan. Selain dalam bentuk penugasan, assesmen lain yang dilakukan adalah tes/ujian tengah semester dan tes/ujian akhir semester.

Langkah ketiga dalam pengembangan metode pembelajaran adalah merancang aktifitas pembelajaran. Dalam penelitian ini, dosen melakukan kolaborasi dengan mahasiswa untuk mengembangkan metode pembelajaran dengan menggunakan metode discoveri learning. Secara garis besar, langkah dalam metode discoveri learning berdasarkan literatur adalah adalah sebagai berikut :

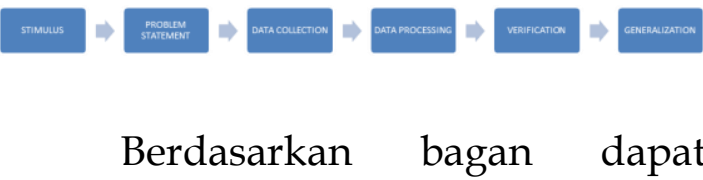
dijelaskan bahwa langkah-langkah dalam pembelajaran discovery (Syah,2004), adalah sebagai berikut:

1. Stimulation (memberi stimulus). Pada kegiatan ini guru memberikan stimulan, dapat berupa bacaan, atau gambar, atau situasi, sesuai dengan materi pembelajaran/topik/tema yang akan dibahas, sehingga peserta didik mendapat pengalaman belajar mengamati pengetahuan konseptual melalui kegiatan membaca, mengamati situasi atau melihat gambar.

2. Problem Statement (mengidentifikasi masalah). Dari tahapan tersebut, peserta didik diharuskan menemukan permasalahan apa saja yang dihadapi, sehingga pada kegiatan ini peserta didik diberikan pengalaman untuk menanya, mencari informasi, dan merumuskan masalah.

3. Data Collecting (mengumpulkan data). Pada tahapan ini peserta didik diberikan pengalaman mencari dan mengumpulkan data/informasi yang dapat digunakan untuk menemukan solusi pemecahan masalah yang dihadapi. Kegiatan ini juga akan melatih ketelitian, akurasi, dan kejujuran, serta membiasakan 
peserta didik untuk mencari atau merumuskan berbagai alternatif pemecahan masalah, jika satu alternatif mengalami kegagalan.

4. Data Processing (mengolah data). Kegiatan mengolah data akan melatih peserta didik untuk mencoba dan mengeksplorasi kemampuan pengetahuan konseptualnya untuk diaplikasikan pada kehidupan nyata, sehingga kegiatan ini juga akan melatih keterampilan berfikir logis dan aplikatif.

5. Verification (memferifikasi). Tahapan ini mengarahkan peserta didik untuk mengecek kebenaran atau keabsahan hasil pengolahan data, melalui berbagai kegiatan, antara lain bertanya kepada teman, berdiskkusi, atau mencari sumber yang relevan baik dari buku atau media, serta mengasosiasikannya sehingga menjadi suatu kesimpulan.

6. Generalization (menyimpulkan). Pada kegiatan ini peserta didik digiring untuk menggeneralisasikan hasil simpulannya pada suatu kejadian atau permasalahan yang serupa, sehingga kegiatan ini juga dapat melatih pengetahuan metakognisi peserta didik.

Metode discoveri learning dalam penelitian ini kemudian dijabarkan dalam penggunaan tehnik pembelajaran yang mengintegrasikan tiga tehnik sekaligus, yaitu magang industri, bedah kasus, dan diskusi kelompok. Langkah pembelajaran melalui tahapan yang dapat digambarkan sebagai berikut :

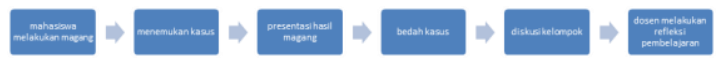

Dari bagan dapat dijelaskan bahwa proses discovery learning dalam proses pembelajaran dimulai dari proses mendapatkan stimulusyang ditandai dengan dengan mahasiswa melakukan magang industri di toko ritel. Kemudian dari proses magang mereka akan menemukan masalah sekaligus mengumpulkan data-data terkait untuk menganalisis masalah tersebut. Masalah dan data-data yang ditemukan selama proses magang selanjutnya dibawa ke kelas dipresentasikan dalam bentuk laporan hasil magang. Laporan yang dipresentasikan (kasus) dibedah bersama kelompok lain dan dilakukan diskusi kelompok untuk membahas kasus tersebut. Setelah proses selesai dosen menyimpulkan dan melakukan refleksi terhadap hasil pembelajaran.

\section{HASIL DAN PEMBAHASAN}

Proses pembelajaran mata kuliah Manajemen Ritel dilaksanakan selama 14 kali pertemuan, ditambah dua kali pertemuan untuk UTS dan UAS. Dari seluruh pertemuan yang direncanakan, rumusan capaian pembelajaran dibagi dalam 4 CPMK. Setiap kali CPMK terlampaui, mahasiswa diberikan tugas secara berkelompok untuk mengukur kemampuan mahasiswa dalam menyerap materi. Setiap tugas yang diberikan juga memasukkan unsur kreatifitas, serta karakter kewirausahaan lainnya, untuk 
mengamati perkembangan karakter kewirausahaan yang dimiliki mahasiswa.

Fase pencapaian CPMK pertama, mahasiswa diajak untuk belajar tentang konsep dasar manajemen ritel, klasifikasi ritel, dan trend bisnis ritel saat ini. Proses pembelajaran belum menggunakan metode magang industri, sehingga metode yang digunakan adalah campuran antara metode ceramah, bedah kasus, dan diskusi kelompok. Karena pada fase ini belum dilakukan magang industri, maka kasus yang dibedah dibuat oleh dosen, untuk memberikan stimulus kepada mahasiswa dalam mengantarkan materi yang akan dipelajari. Lebih jelasnya, proses pembelajaran dimulai dengan dosen memberikan kasus untuk dibedah. Kemudian mahasiswa masuk dalam kelompok yang sudah ditentukan untuk berdiskusi membedah kasus yang sudah diberikan. Setelah diskusi kelompok selesai, dilakukan diskusi panel kelas, dengan menunjuk tiga perwakilan kelompok untuk mempresentasikan hasil diskusi kelompok, kemudian kelompok lain menanggapi. Setelah selesai proses diskusi, dosen memberikan refleksi tentang jalannya proses diskusi, dan menambahkan materi terkait secukupnya.

Fase pencapaian CPMK kedua, ketiga, dan keempat, metode pembelajaran yang digunakan sudah menggabungkan metode magang industri-bedah kasus-diskusi kelompok. Setiap mahasiswa dalam Dalam proses magang mahasiswa akan melakukan unjuk kerja yang sudah tertuang dalam rencana pelaksanaan pembelajaran (RPP) magang. Tujuan dari magang industri adalah memberikan pengalaman praktek langsung kepada mahasiswa terkait dengan pekerjaan-pekerjaan ritel. Diakhir magang mahasiswa harus membuat laporan magang menggunakan template yang sudah diberikan dan membuat kasus terkait dengan ritel berdasarkan pengalaman yang lapangan. Selama satu semester, ada 16 kelompok magang dari kelas $\mathrm{A}$ dan B yang terdiri dari 78 mahasiswa. Pada program magang kali ini disepakati tempat magang industri ada dua, yaitu Syar'i Mart dan Techno Smart Centre. Syar'i Mart adalah toko ritel yang dimiliki oleh Universitas Islam Indonesia, berlokasi di dalam kampus Jl Kaliurang km 14,5 dan bergerak di bidang ritel produk kebutuhan sehari-hari, alat tulis, dan makanan. Sedang Smart Techno Centre adalah toko ritel yang dimiliki oleh perseorang, berlokasi di Jl Kepitu Sleman (15 menit dari kampus UII), dan bergerak di bidang ritel produk perlengkapan dan alat-alat masjid. Keputusan memilih Syar'i Mart sebagai tempat magang karena sebagai satu-satunya toko ritel yang dimiliki Prodi D3 Ekonomi, diharapkan ke depan bisa menjadi laboratorium bagi mahasiswa dalam melaksanakan kuliah praktek di bidang ritel dan kewirausahaan. Sementara pemilihan Techno Smart Centre menggunakan pertimbangan kemudahan akses dan perijinan, serta ritel ini sudah menggunakan sistem online dalam melakukan penjualan produknya. Untuk melakukan evaluasi dan monitoring aktifitas dan keaktifan kegiatan magang, setiap mahasiswa diberikan kartu laporan magang yang berisi kegiatan harian 
mahasiswa selama magang, dan di akhir magang kartu tersebut harus ditandatangani oleh supervisor atau pendamping yang ditunjuk ditempat magang. Selain itu pendamping atau supervisor juga diberikan kartu penilaikan untuk menilai kinerja dan keaktifan mahasiswa yang bersangutan selama magang.

Setelah mahasiswa melakukan magang, mereka harus mempresentasikan laporan magang di depan kelas. Saat sesi presentasi, kelompok magang harus mentransfer pengalaman melakukan unjuk kerja, hal ini dimaksudkan agar mahasiswa yang tidak mengalami secara langsung unjuk kerja yang terkait, akan mendapat gambaran secara langsung bagaimana pelaksanaan unjuk kerja. Selama proses magang, rencana pelaksanaan pembelajaran (RPP) yang sudah dirancang bisa dilaksanakan semua.

Pada sesi bedah kasus, kelompok magang akan mengajukan kasus yang mereka lihat atau alami selama proses magang industri. Kasus yang mereka ajukan kemudian akan dibedah oleh kelompok lain dalam diskusi kelompok. Selanjutnya hasil diskusi kelompok dibawa dalam diskusi panel kelas, untuk dicari solusinya bersama-sama.

Dalam penelitian kali ini, selain mahasiswa melakukan proses pembelajaran dengan metode yang sudah dijelaskan diatas, mahasiswa juga mendapat tambahan kuliah pakar. Pada sesi ini didatangkan dosen tamu seorang pakar sekaligus pelaku bisnis di bidang ritel untuk memberikan motivasi sekaligus pencerahan kepada mahasiswa terkait dengan dunia ritel.
Terakhir, untuk mendukung perkuliahan, juga digunakan media pembelajaran online dalam bentuk klasiber, untuk proses mengunggah naskah penugasan dan output penugasan, serta mengunggah materi-materi terkait.

Berikut adalah hasil capaian dan keluaran selama proses pembelajaran.

Tabel 1. Capaian dan Luaran Pembelajaran Mata Kuliah Manajemen Ritel

\begin{tabular}{|c|c|c|c|c|c|}
\hline \multirow{2}{*}{$\begin{array}{l}\text { Indikator } \\
\text { Kinerja }\end{array}$} & \multirow{2}{*}{$\begin{array}{l}\text { Base } \\
\text { line }\end{array}$} & \multirow[t]{2}{*}{ Target } & \multicolumn{3}{|c|}{ Pencapaian } \\
\hline & & & $\begin{array}{l}\text { Kelas } \\
\text { A }\end{array}$ & $\begin{array}{l}\text { Kelas } \\
\text { B }\end{array}$ & Rata2 \\
\hline $\begin{array}{l}\text { Persent } \\
\text { ase } \\
\text { mahasi } \\
\text { swa } \\
\text { dengan } \\
\text { nilai } \geq \\
\text { B } \\
\text { untuk } \\
\text { tugas } \\
\text { membu } \\
\text { at peta } \\
\text { konsep } \\
\text { (CPMK } \\
\text { 1) }\end{array}$ & $\begin{array}{l}74 \\
\%\end{array}$ & $75 \%$ & $60 \%$ & $98 \%$ & $79 \%$ \\
\hline $\begin{array}{l}\text { Persent } \\
\text { ase } \\
\text { mahasi } \\
\text { swa } \\
\text { dengan } \\
\text { nilai } \geq \\
\text { B } \\
\text { untuk } \\
\text { tugas } \\
\text { analisis } \\
\text { kasus } \\
\text { (CPMK } \\
\text { 2) }\end{array}$ & $\begin{array}{l}74 \\
\%\end{array}$ & $75 \%$ & $90 \%$ & $98 \%$ & $94 \%$ \\
\hline $\begin{array}{l}\text { Persent } \\
\text { ase } \\
\text { mahasi } \\
\text { swa } \\
\text { dengan } \\
\text { nilai } \geq \\
\text { B } \\
\text { untuk } \\
\text { tugas } \\
\text { merum }\end{array}$ & $\begin{array}{l}74 \\
\%\end{array}$ & $75 \%$ & $90 \%$ & $98 \%$ & $94 \%$ \\
\hline
\end{tabular}




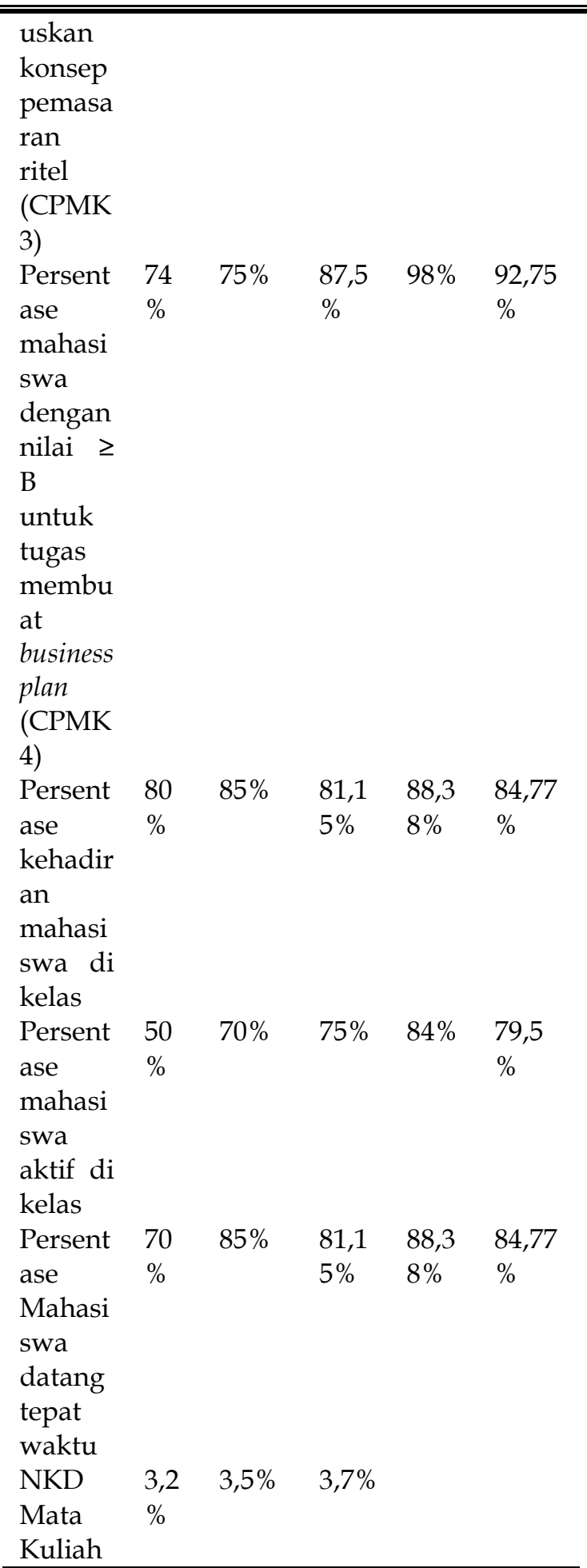

Upaya yang kreatif dalam memodifikasi metode pembelajaran akan menciptakan lingkungan belajar yang kondusif dan menyenangkan. Lingkungan yang kondusif dan menyenangkan akan menciptakan motivasi dan keaktifan belajar mahasiswa. Ketika motivasi belajar sudah terbangun, maka niat dan upaya mahasiswa akan optimal, sehingga akan menghasilkan output pembelajaran yang optimal. Metode discovery learning melatih mahasiswa untuk mengasah kemampuan berfikir analitis dan sistematis dalam menghadapi masalah yang ditemui dalam kehidupan sehari-hari. Kemampuan ini akan membangun skill dan karakter mahasiswa dalam menelurkan ide kreatif, kritis, dan berani mengungkapkan serta menuangkan ide kreatifnya dalam gagasan yang menantang. Skill inilah yang menjadi modal utama menjadi seorang wirausaha. Selain mahasiswa, dosen sebagai pengajar pun jadi tertantang untuk belajar secara terus menerus mengasah kemampuan teoritis dan analitisnya, terutama untuk mengimbangi keaktifan mahasiswa dalam mengungkapkan kasus-kasus di kelas. Efektifitas pelaksanaan metode discovery learning ini terlihat pada tiga hal, pertama, pada saat persiapan perkuliahan baik dosen maupun mahasiswa bekerja sama dalam merencanakan proses pembelajaran, seperti membuat kontrak belajar, jadwal magang, dan mencari tempat magang. Kedua saat proses pembelajaran, mahasiswa menjadi aktif dalam melakukan proses magang, menemukan kasus baru di tempat magang, serta lebih kreatif dalam mengusulkan program pengembangan business plan untuk tempat magang. Ketiga, hasil pembelajaran, menunjukkan data 
capaian yang melebihi target yang disusun oleh dosen.

Secara khusus, dampak penelitian terhadap pelaksanaan pembelajaran mata kuliah manajemen ritel juga signifikan. Berikut dampak positif yang dirasakan selama pelaksanaan pembelajaran.

a. Mahasiswa lebih mudah memahami materi, sehingga proses belajar menjadi lancar.

b. Mahasiswa memiliki media untuk mempraktekkan langsung teori yang di dapat melalui pengalaman magang.

c. Pencapaian CPMK kelas meningkat.

d. Kinerja dosen meningkat ditinjau dari pencapaian NKD mata kuliah yang bersangkutan, dan capaian keluaran pembelajaran berupa ketersediaan RPS, RPP magang, handout mata kuliah, serta SOP magang bagi mahasiswa. Hal ini dimungkinkan karena selama proses pembelajaran satu semester dosen juga mengikuti workshop perumusan RPS dan menyempurnakan handout yang sudah ada disesuaikan dengan penggunaan metode discovery leraning.

\section{KESIMPULAN}

Berdasarkan hasil capaian dan keluaran proses pembelajaran dapat disimpulkan bahwa seluruh CPMK yang ditetapkan capaian pembelajarannya terpenuhi yaitu lebih besar atau sama dengan $79 \%$. Begitu juga untuk tingkat keaktifan, dan kehadiran mahasiswa juga melampaui target yang ditetapkan yaitu lebih besar atau sama dengan 79,5\%. Disisi lain, produktifitas dosen juga tergambar dalam capaian keluaran berupa ketersedian RPS, RPP magang, handout, serta SOP magang. Ini mencerminkan bahwa metode discovery learning memberikan dampak positif dalam proses pembelajaran, baik bagi mahasiswa maupun dosen.

\section{DAFTAR PUSTAKA}

Hanafiah, Suhana. 2009. Konsep Strategi Pembelajaran. Bandung: Refika Aditama

Hermansyah a., Natuda A.D., dan Sumarno. 2017. Kontribusi Pelaksanaan Pembelajaran Kewirausahaan dan Interaksi Sosial Terhadap Karakter Kewirausahaan Peserta Didik MAN 1 Pekanbaru. Pekbis Jurnal, Vol 9 No2, Juli 2017

Kementerian Pendidikan dan Kebudayaan. 2014. Modul Pelatihan Implementasi Kurikulum 2013 SMP Bahasa Inggris. Jakarta: Badan Pengembangan Sumberdaya Manusia Pendidikan dan Kebudayaan dan Penjaminan Mutu Pendidikan Kementrian Pendidikan dan Kebudayaan

Kementerian Pendidikan dan Kebudayaan. 2014. Peraturan Menteri Pendidikan dan Kebudayaan Republik Indonesia nomor 58 tahun 2014 tentang Kurkulum 2013 Sekolah Menengah Pertama/Madrasah Tsanawiyah 
Kementerian Pendidikan dan Kebudayaan. 2014. Peraturan Menteri Pendidikan dan Kebudayaan Republik Indonesia nomor 103 tahun 2014 tentang Pembelajaran Pada Pendididan Dasar dan Menengah

Lorz, Michael. 2008. The Impact of Entrepreneurship Education on Entrepreneurial Intention. Dissertation of the University of St. Gallen, School of Management, Economics, Law, Social Sciences and International Affairs.

Maisaroh, Dharmawan. 2017. Pengaruh Faktor Individu dan Pendidikan Kewirausahaan Terhadap Intensi Kewirausahaan Pada Mahasiswa D3 Ekonomi Fakultas Ekonomi Universitas Islam Indonesia. Proceeding FMI 9, November 2017

McClelland. 2006. Memacu Masyarakat Berprestasi. Jakarta: CV Intermedia

Meredith, Geoffrey G, et.al,. 1996. Kewirausahaan Teori dan Praktek. Jakarta, Pustaka Binaman Pressindo

Mutis, Thoby. 1995. Pembangunan Koperasi. Jakarta: Yayasan Bina Bakti Utama.

Novan, Wiyani. 2013. Desain Pembelajaran Pendidikan: Tata Rancang Pembelajaran Menuju Pencapaian Komptensi. Yogyakarta: Ar-Ruzz Media.
Sanjaya. 2006. Strategi Pembelajaran. Jakarta, Kencana Prenada Media Group

Shah Muhibbin. 2004. Psikologi Pendidikan Suatu Pendekatan Baru. Bandung: Remaja Rosdakarya.

Suryana. 2003. Kewirausahaan, Pedoman Praktis, Kiat, dan Proses Menuju Sukses. Jakarta, Salemba Empat

Widodo, Muladi. 2011. Pembelajaran Kewirausahaan dan Minat Wirausaha Lulusan SMK. Eksplanasi Volume 6 Nomor 2 Edisi September, halaman 109122. 